\title{
Evaluating the role of the working environment on to skin and upper respiratory tract microbiota of museum workers
}

\author{
IULIANA PAMELA SCARLAT ${ }^{1,2 *}$, ROXANA STROE ${ }^{2}$, LIA-MARA DIȚU ${ }^{3}$, CARMEN \\ CURUȚIU $^{3}$, ELENA RUXANDRA CHIURTU ${ }^{4}$, IOANA STĂNCULESCU ${ }^{5}$, MARIANA \\ CARMEN CHIFIRIUC ${ }^{3}$ and VERONICA LAZĂR ${ }^{3}$
}

\begin{abstract}
${ }^{1}$ The National Institute of Research and Development on Occupational Safety "Alexandru Darabont" Bucharest, Laboratory Chemical and Biological Risks Bucharest, Romania

${ }^{2}$ University of Bucharest, Department of Microbiology, Faculty of Biology, Bucharest, Romania

${ }^{3}$ University of Bucharest, Department of Microbiology, Faculty of Biology and The Research Institute of the University of Bucharest, Bucharest, Romania

${ }^{4}$ The National Institute of Research and Development on Occupational Safety "Alexandru Darabont" Bucharest, Laboratory Chemical and Biological Risks Bucharest, Romania; Co-opted member of Risk Assessment Committee (RAC), European Chemicals Agency (ECHA), Helsinki, Finland

${ }^{5}$ Horia Hulubei National Institute for Development of Physics and Nuclear Engineering; University of Bucharest, Faculty of Chemistry, Department of Physical Chemistry, Romania
\end{abstract}

\begin{abstract}
Aims: The aim of the study was the investigation of the composition of cultivable microbiota colonizing the skin and the upper respiratory tract mucosa of museum workers, in order to evaluate the potential occupational risk to their health and wellbeing.

Methods: This study was voluntarily attended by 50 workers of a Romanian museum, for which their hands, noses and throats were sampled using sterile swabs.The API tests were used to identify the $\beta$-hemolytic strains, and penicillin and the cefoxitin susceptibility test was performed for Staphylococccus sp. strains.

Results: This study showed that a high percentage of the museum workers presented changes in the normal oropharyngeal and skin cultivable microbiota, indicated by the presence of dysbiosis, $\beta$-hemolytic microorganisms, methicillin and penicillin resistant staphylococci. The identification step revealed species of staphylococci which showed high levels of resistance to penicillin and methicillin.

Conclusions: The highlighted opportunistic and antibiotic resistant bacterial strains may be a risk factor for workers. The work environment should be further investigated as a possible source of contamination, since some of the species identified in the present study were also identified in a former study, made in the same museum, showing the possibility that contamination has occurred at the workplace.
\end{abstract}

Keywords Occupational diseases, work environment, health, workers, microorganisms, contamination, museums, artifacts.

To cite this article: SCARLAT IP, STROE R, DIŢU LM, CURUȚIU C, CHIURTU ER, STĂNCULESCU I, CHIFIRIUC MC, LAZĂR V. Evaluating the role of the working environment on to skin and upper respiratory tract microbiota of museum workers. Rom Biotechnol Lett. 2020; 25(6): 2103-2106. DOI: 10.25083/rb1/25.6/2103.2106

IULIANA PAMELA SCARLAT, The National Institute of Research and Development on Occupational Safety "Alexandru Darabont" Bucharest, Romania; University of Bucharest, Department of Microbiology, Faculty of Biology, Bucharest, Romania E-mail: scarlatpamela@yahoo.com 


\section{Introduction}

Human microbial exposure is common in many work settings and could have serious consequences to the workers' health (LIEBERS V, RAULF-HEIMSOTH M, BRÜNING T, 2008). Museums are among the crucial institutions involved in preserving the cultural heritage and offer diverse working environments for different specialists (archivists, curators, conservators, storeroom workers and office staff), many of these media having shown a high microbial air contamination (SKÓRA J, GUTAROWSKA B, PIELECH-PRZYBYLSKA K, et al, 2015).

Inside museums, microbial contamination does not only threaten with biodegradation of cultural heritage artifacts, but also represents a health risk for workers (GÓRNY RL et al, 2016). Microclimate factors (humidity, temperature, air currents, etc.) and organic nutrients offered by museum objects (leather, paper, wood, etc.) offer appropriate conditions for microbial development. Moreover, new microorganisms are also introduced in the museum environment by visitors and museum workers (NIESLER A et al, 2010).

The statistics show that the number of employees in the cultural workplace is rising (EUROSTAT/ 2018), while health and safety at work are still a priority of the entire European Union. In Romania, in 2017, there were reported 762 museums and public collections - in which 6989 employees are working (INSR/2019). Eurostat data show that $7,9 \%$ of the workforce suffered from occupational health problems, of which $36 \%$ resulted in absence from work for at least 4 days (Eurostat, 2018a, 2018c). The negative effects can be huge, starting from absenteeism and high medical costs or insurance premiums or the presence of sick workers (with the risk of mistakes occurring during the execution) until early retirement and loss of qualified personnel. The European Agency for Safety and Health at Work (EU-OSHA) estimated 3,9\% of the global total gross domestic product (GDP) and 3,3\% of European GDP is spent on occupational diseases or injuries (EU-OSHA, 2019). This percentage varies from country to country.

In recent years, more and more studies on the microbial contamination in museums, heritage archives or libraries are being conducted. However, the scientific papers usually focus on microbial contamination of the museum or library collections themselves, while the workers' exposure is ignored (JANKIEWICZ KZ et al, 2008; GORNY RL et al, 2016).

Health threats in museums frequently occur due to fungal contamination of objects and air, causing different afflictions, from allergies to fungal infections or mycotoxicoses (VIEGAS S et al, 2018). Fungal infections can be lethal in immuno-deficient individuals (PFALLER MA; DIEKEMA DJ). Microfungi species, such as Candida, Aspergillus, Penicillium, Alternaria, Cladosporium, Mucor, Rhizopus, Trichoderma, Fusarium, Acremonium, Scedosporium, Paecilomyces, Botrytis, Chrysonila and Aureobasidium, (JANKIEWICZ, KZ, 2008; GUTAROWSKA B et al, 2012; PFALLER MA; DIEKEMA DJ), and bacterial strains such as Staphylococcus epidermidis, S. haemolyticus and Bacillus sp. (HAIDUCU M et al, 2014) were often mentioned in studies that examined the presence of microorganisms in indoor air of museums, archives or libraries. Epidemiological studies claim that healthy individuals develop sensitivity if they are exposed for a long time to different microbial contaminants (KALWASINSKA A; BURKSANDRA A; WILK I, 2012).

Studies on the seasonal monitoring of bacteriological and fungal contamination of museums work environment are few, and however, they usually focus on microbial contamination of the museum collections themselves, while the exposure of workers is ignored, potentially leading to inappropriate management of occupational health and safety issues. This is the first study reporting on the characterization of culturable skin and upper respiratory tract microbiota of museum employees in Romania.

\section{Materials and Methods}

The employees enrolled in this study are working in one of the most visited museums in Romania, located in the south of the Southern Romanian Carpathians, in a region with very rich vegetation.

Out of the total number of 140 employees, 50 agreed to participate in this study as volunteers.

Of these participating, 38 were women with average age of around 46 years and 12 were men, with an average age of 39 years.

All volunteers have signed an informed consent, stating the purpose of the study in which they participated; the sampling procedures; their rights as volunteers; risks and/or possible discomforts; details of confidentiality of analytical results.

It is worth mentioning that only 36 of them accepted to give all three types of samples (nose, throat, hands). The swab samples were collected using standardized protocols used in the clinical laboratory. The swabs were transported to the laboratory in Amies transport medium, cultivated to blood agar and incubated in aerobic and anaerobiosis conditions for 24 hours at $37^{\circ} \mathrm{C}$. All samples were analyzed for assessing the number of the developed colonies and the hemolysis reaction. After Gram staining and microscopic visualization, the catalase test was performed.

All beta-hemolytic and catalase-positive colonies revealing Gram-positive cocci were tested for penicillin $10 \mathrm{IU}$ and cefoxitin $(30 \mu \mathrm{g})$ susceptibility following the CLSI recommendations. The catalase-negative colonies revealing Gram-positive cocci were tested for agglutination with BioMerieux Slidex Staph-Kit. Depending on the microscopic aspects, API identification tests were used for the rest of the bacterial strains.

\section{Results}

The purpose of this study was to investigate the culturable skin and respiratory tract microbiota of museum workers in order to evaluate the influence of the working environment on the health of museum workers. 
The analyzed parameters for an abnormal microbiota were: i) presence of dysbiosis, defined by the recovery of one single colony type from the analyzed samples; ii) the presence of $\beta$-haemolytic colonies; iii) the presence of fungal colonies. The results obtained are presented in Figure 1.

\section{Frequency of abnormal parameters recorded for the analyzed group}

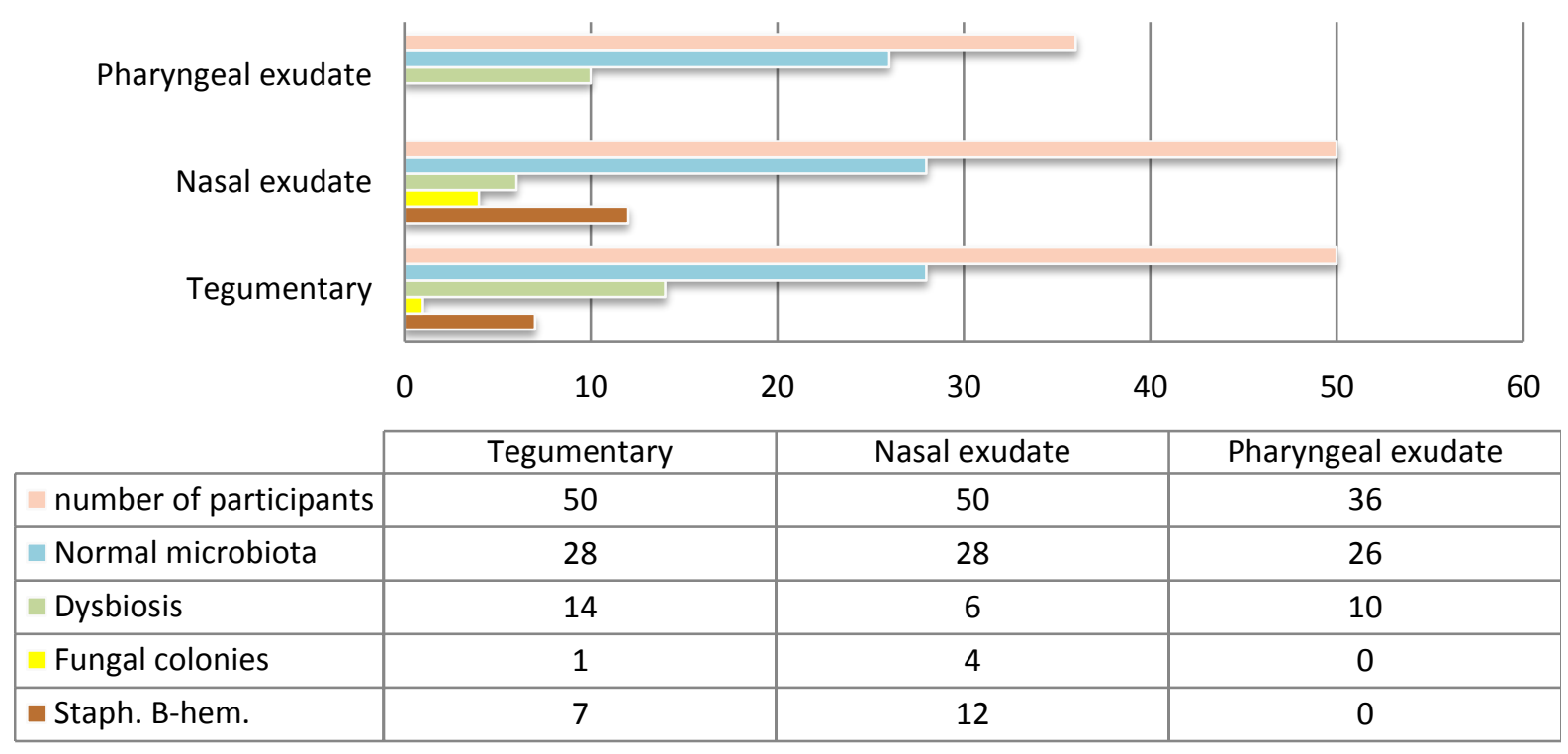

Figure 1. Study to investigate the culturable skin and respiratory tract microbiota of museum workers.

From the 50 volunteers, only $28(56 \%)$ exhibited had normal results following the skin and nasal swabs analysis, while from the 36 participants agreeing to give throat swabs, $26(72.2 \%)$ had a normal aspect of cultivable microbiota. From the investigated parameters, dysbiosis was the most frequent abnormal condition encountered in the study, followed by the presence of $\beta$-haemolytic colonies.

Of the 27 isolated haemolytic Staphylococcaceae strains (Gram-positive cocci, catalase-positive), 24 of them showed resistance to penicillin and/or cefoxitin (Table 1), indicating the high rate of methicillin resistance in the analyzed population group.

Table 1. Antibiotic susceptibility testing of Staphylococcaceae strains

\begin{tabular}{l|l}
\hline Antibiotics & $\boldsymbol{C F U}^{*}$ \\
\hline Resistance to Penicillin and Cefoxitin & 20 \\
Resistance to Cefoxitin, sensitive Penicillin & 4 \\
Sensitive to Penicillin and Cefoxitin & 3 \\
\hline
\end{tabular}

* CFU - Colony Forming Units

API tests did not reveal the presence of Staphylococcus aureus, but other species have been identified, such as: Staphylococcus xylosus, the most frequent species (62\%), followed by Staphylococcus haemolyticus (21\%), Staphylococcus epidermidis $(13 \%)$ and Staphylococcus sciuri $(4 \%)$. These strains have been mainly identified from nasal exudates, while $S$. epidermidis was identified only in skin samples.

The density of skin microorganisms is normally about $10^{7} / \mathrm{cm}^{2}$ (DIMA MB et al, 2018). It has been shown that skin microbiota dysbiosis can be driven by the overgrowth of a certain species. For example, a US study performed in 2016 (DIMA MB et al, 2018) showed that commensal Gram-negative bacteria from healthy individuals are inhibited by the growth of Methicillin-Resistant Staphylococcus aureus.

In the present study, even though there was a large number of participants with dysbiosis, Staphylococcus aureus was not isolated. However, other Staphylococcus sp. strains were isolated and many of them were resistant to antibiotics, as for example Staphylococcus sciuri. There are studies that claim the PBP2a protein from $S$. sciuri has $88 \%$ amino acid sequence identity to methicillin-resistant S. aureus PBP2a (ZEMAN M et al, 2017).

Only a small percentage of the tested woekers harbored fungi on skin or nasal mucosa (1 versus 4 ).

The findings in this study can be correlated with findings from a former study that was conducted within a similar setup, in 2017, as part of the TEXLECONS project. Out of the four seasonal measurements, the maximum values recorded for mesophilic microorganisms were $1.4 \times 10^{4} \mathrm{CFU} / \mathrm{m}^{3}$, for hemolytic bacteria $350 \mathrm{CFU} / \mathrm{m}^{3}$ and for fungi up to $3 \times 10^{3} \mathrm{CFU} / \mathrm{m}^{3}$ (SCARLAT I et al, 2017). Some of the bacterial strains identified on the workers skin and mucosa have been also isolated from the museum environment, hence suggesting that the workplace may indeed 
be contaminated by artifacts and indoor air, thus raising the need to further investigate the artifacts and indoor air within the workplace as a possible source of contamination.

\section{Conclusions}

This study demonstrates that microorganisms present in the work environment of museums can have effects on the health of workers. The results obtained show that more than half of the volunteer workers have values deviate from the reference values in at least one of the analyses, represented by the presence of dysbiosis, $\beta$-hemolytic microorganisms, methicillin and penicillin resistant staphylococci and, less frequently fungal colonization of skin and nasal mucosa. The work environment should be further investigated as a possible source of contamination, since some of the species identified in the present study were also identified in a former study, conducted in the workplaces of the investigated persons, showing the possibility that contamination has occurred at the workplace.

\section{Acknowledgements}

This work was funded by the Safe security and Health at Work - SSM, PN Code 18-18 project, "Analyzing worker exposure to biological agents by studying specific biological indicators in order to improve the assessment, control and awareness of the associated professional risks (The Nucleus Program)", contract no. 11N/2018.

\section{References}

1. LIEBERS V, RAULF-HEIMSOTH M, BRÜNING T. Health effects due to endotoxin inhalation (review). Arch Toxicol. 2008; 82(4):203-10.

2. SKÓRA J, GUTAROWSKA B, PIELECH-PRZYBYLSKA $\mathrm{K}$ et al. Assessment of microbiological contamination in the work environments of museums, archives and libraries. Aerobiologia (Bologna). 2015; 31(3):389-401. doi:10.1007/s10453-015-9372-8

3. GÓRNY RL, HARKAWY A.S, ŁAWNICZEKWAŁCZYK A, KARBOWSKA-BERENT J, WLAZŁO A, NIESLER A, GOŁOFIT-SZYMCZAK M, CYPROWSKI M. Exposure to culturable and total microbiota in cultural heritage conservation laboratories. International Journal of Occupational Medicine and Environmental Health. 2016 29(2) 255-75. doi: 10.13075/ijomeh.1896.00630

4. NIESLER A, WLAZŁO A, GÓRNY RL, WALCZYK AL, SZYMCZAK MG, MERES Z, KOCOT KJ, HARKAWY A, LIS D.O, ANCZYK E. Microbial contamination of storerooms at the AuschwitzBirkenau Museum. Aerobiologia, 2010.

5. NICHOLSON LB. The immune system. Essay Biochemistry; 2016 Oct. 31; 60(3):275-301. doi: 10.1042/EBC20160017

6. JANKIEWICZ KZ, KOZAJDA A, PIOTROWSKA M, SZADKOWSKA SI. Microbiological contamination with moulds in work environment in libraries and archive storage facilities. Ann Agric Environ Med, 2008, 15, 71-78.
7. SCARLAT IP, LAZAR V, STEPA R, CHIFIRIUC MC, DITU LM, HAIDUCU H. Seasonal monitoring of microbiological air contamination from a museum a case study. MATEC Web of Conferences, 121, Sibiu, Romania, 2017.

8. EUCAST guidelines for detection of resistance mechanisms and specific resistances of clinical and/or epidemiological importance; European Committee on Antimicrobial Susceptibility Testing; 2017.

9. PFALLER MA, DIEKEMA DJ. Rare and Emerging Opportunistic Fungal Pathogens: Concern for Resistance beyond Candida albicans and Aspergillus fumigatus/Journal of Clinical Microbiology. 42(10): 4419-4431, 2004 Oct.

10. KALWASINSKA A, BURKSANDRA A, WILK I. Microbial air contamination in indoor environment of a university library. Annals of Agricultural and Environmental Medicine, vol. 19, no 1, 25-29, 2012.

11. GUTAROWSKA B, SKORA J, ZDUNIAK K, REMBISZ D. Analysis of the sensitivity of microorganisms contaminating museums and archives to silver nanoparticles. International Biodeterioration \& Biodegradation, vol. 68, page. 7-17, March 2012.

12. LADEIRA C, VIEGAS S. Application of human biomonitoring programmes in occupational exposure contexts: an overview. Arezes et al, editors. Proceedings book of the International Symposium on Occupational Safety and Hygiene - SHO2016. Guimarães: SPOSHO; 2016. p. 123-5.

13. VIEGAS S, VIEGAS C, OPPLIGER A. Occupational Exposure to Mycotoxins: Current Knowledge and Prospects, Annals of Work Exposures and Health, volume 62, Issue 8, October 2018, pages 923-941.

14. EUR $14988 \mathrm{EN}$, Commission of the European Communities, Biol. Particles in indoor environments, 12, (1993);

15. HAIDUCU M, ŞTEPA R, NISIPEANU S, SCARLAT I, STANCULESCU I, MOISE V. Modern methods to prevent occupational diseases for workers and reducing biological risk factors in museums. International Multidisciplinary Scientific Conference on Social Sciences and Arts - SGEM 2014, Albena, Bulgaria - poster.

16. DIMA MB, ORZAN, OA, POPA GL, DIMA B, MIHAI MM. The altered skin microbiota - keey role in atopic dermatitis?, Medichub Media, DOI: 10.26416/ Inf.53.1.2018

17. ZEMAN M, MASLANOVA I, IDRAKOVA A, SIBOROVA M, MIKULASEK K, BENDICKOVA K, PLEVKA P, VRBOSKA V, ZDRAHAL Z, DOSKAR J, PANTUCEK R. Staphylococcus sciuri bacteriophages double-convert for staphylokinase and phospholipase, mediate interspecies plasmid transduction, and package mecA gene. Scientific Reports 7, 2017.

18. TOMPA E, MOFIDI A, HEUVEL S, BREE T, MICHAELSEN F, JUNG Y, PORSCH L, EMMERIK $M$. The value of occupational safety and health and societal costs of work-related injuries and diseases. European Agency for Safety and Health at Work, Luxembourg, 2019. 